\title{
Physical Education in the COVID-19 context. A tale from teachers of different educational stages \\ La Educación Física en el contexto COVID-19. Un relato de profesores de diferentes etapas educativas \\ *David Hortigüela-Alcalá, *Alejandra Hernando-Garijo, **Ángel Pérez-Pueyo \\ *U niversidad de Burgos (España), **U niversidad de León (España)
}

\begin{abstract}
The way in which Physical Education (PE) is conceived has changed radically in a matter of months. This means that the professional identity of the teaching staff has had to be reconstructed and adapted to an unprecedented situation. The aim of this study is, under the theory of teaching identity and professional reconstruction, to contrast how three groups of teachers from different educational stages teach PE with COVID 19, analyzing the adaptations made in the classroom. Five university teachers, seven school teachers and eight future teachers took part. A qualitative analysis was employed, using reflective journals and discussion groups as data collection instruments. Three categories of analysis were used: a) reconfiguration of the purpose of the subject; b) reconstruction of professional identity; c) main limitations of teaching and solutions found. The results show how teachers in the three educational stages agree on the negative implications of teaching the subject with physical distance. University teachers stress the need to reconsider the aims of the subject in order to adapt to this new situation, while school teachers admit to being very limited on the content to be taught. For their part, the future teachers express great insecurity about being able to apply what they have been taught throughout their university training. It is considered essential to continue researching and reflecting on the evolution of PE teaching in the situation of COVID 19, as well as the curricular and educational role that it should continue to play.
\end{abstract}

Keywords: Physical Education; COVID 19; professional identity; perception of teachers; teaching constraints.

Resumen. La forma de concebir la educación física ha cambiado radicalmente en cuestión de meses. Esto hace que la identidad profesional del profesorado haya tenido que reconstruirse y adaptarse a una situación inédita. El objetivo de este estudio es, bajo la teoría de laidentidad docente y la reconstrucción profesional, contrastar cómo tres grupos de profesores de diferentes etapas educativas enseñan Educación Física con la COVID 19, analizando las adaptaciones realizadas en el aula. Participaron cinco profesores universitarios, siete profesores de escuela y ocho futuros profesores. Se empleó un análisis cualitativo, utilizando diarios de reflexión y grupos de discusión como instrumentos de recogida de datos. Se utilizaron tres categorías de análisis: a) reconfiguración del propósito de la asignatura; b) reconstrucción de la identidad profesional; c) principal es limitaciones de la enseñanza y soluciones encontradas. Los resultados muestran cómo los profesores de las tres etapas educativas coinciden en las implicaciones negativas de la enseñanza de la asignatura con distanciafísica. Los profesores universitarios destacan lanecesidad de reconsiderar los objetivos de laasignatura para adaptar seaestanuevasituación, mientras que los profesores de la escuela admiten estar muy limitados en cuanto a los contenidos a impartir. Por su parte, los futuros profesores manifiestan una gran inseguridad parapoder aplicar lo que se les ha enseñado alo largo de su formación universitaria. Se considera imprescindible seguir investigando y reflexionando sobre la evolución de la enseñanza de la educación física en la situación de la COVID 19, así como el papel curricular y educativo que debe seguir desempeñando.

Palabrasclave. Educación Física; COVID 19; identidad profesional; percepción delosprofesores; limitaciones delaenseñanza

\section{Introduction}

Teaching approaches are directly connected to political, social and economic spheres, leading to a variety of occasions in conflict situations (Håkansson, Kronlid \& Östman, 2019). It is unquestionable that education, and therefore the education systems that regulate it, are changing and adapting to the new

Fecha recepción: 06-12-20. Fecha de aceptación: 15-02-21

David Hortigüela-Alcalá

dhortiguela@ ubu.es demands of society. This constant adaptation entails an updating by teachers that influences their professional identity and, as a consequence, the way in which they teach and transform reality (Woodrow \& Caruana, 2017). The situation of the pandemic caused by the COVID 19 has meant the greatest social and educational change in recent decades, to which we can also add the uncertainty generated with regard to the future. This uncertainty and instability affects the entire educational curriculum without exception, with PE being one of the most affected subjects. Fundamental and indisputa ble principles such as the promotion of social relations, 
body contact and the work of the emotions are clearly conditioned by the imposition of the use of the mask and distance between students, which results in the existence of absent bodies (Varea $\&$ González-Calvo, 2020). This makes it necessary to redefine the aims of the course, substantially modifying the practices that the teaching staff had been implementing for so many years. Furthermore, this pandemic ismassively attacking the entire world population, so these structural changes in teaching models must be carried out with great caution and in accordance with established heal th protocols. The main challenge lies in continuing to guarantee something as necessary as the learning of in-depth subject content (Herold \& Waring, 2017). For this learning to take pla ce, the use of pedagogical models is essential, due to the scientific evidence that supports them To this end, it is essential that they are applied in a reflective and critical manner. (Landi, Fitzpatrick \& M cGlashan, 2016).

It is essential that PE teachers know how to manage this uncertainty based on the reconstruction of their professional identity, adapting new formulas for action that can be applied to their context in order to continue to respect the pedagogical goals and the learning of knowledge of the subject (Backman \& Barker, 2020). This is where the theory of teaching identity and professional reconstruction comes into play (MacLure, 1993), which structures the ideology of this research. This theory establishestheneed for all teachersto discuss with themselves so that their identity is configured as an ethical imperative that guarantees their commitment to the profession. This identity has a strong ethical and political character that implies a self-reflection that overcomes the most repressive cultural and social discourses of power (Foucault, 1997). This theory seeks constant reflection on the part of the teacher, with the understanding that teaching takes into account a variety of variables that must be taken into account. In addition, it favours the modification of the educational contexts in which teaching practice is developed, allowing them to face constant challenges on a daily basis. This means looking for practical and real solutions to the practices that have been carried out in the past.

In this sense, it is essential to pay attention to the perception that PE teachers have about the new way of conceiving and teaching the subject in this situation of the COVID 19. Furthermore, it is interesting to do so with teachers from different educational stages, as this allows for an analysis, from a broader spectrum, of how curricular and contextual aspects influence their professional reconstruction. Each educational stage is framed in a specific context, so it is essential that, in a health alert situation of this type, the teacher has resources to be able to solve the problems that arise. This is even more relevant in subjects such as PE, in which the body isthe fundamental axis of learning. Under this approach, this research addresses, from a reflective perspective, how PE teachers, from different educational stages, reconfigure the subject, reconstruct their professional identity and seek solutions to the limitations encountered in their day-to-day work. It is precisely on the basis of these categories that the results presented are structured.

The aim of this research is to contrast how three groups of teachersfrom different educational stages teach PE with the COVID 19, analyzing the adaptations made in the classroom. This represents a significant contribution to the existing literature on the subject, since, to date, nothing has been published regarding the way in which teachers from different educational stages (including future teachers) reconfigure their educational action according to the aims of the subject, reflect on their professional identity and express the problems and solutions found for teaching in this situation of the COVID 19. This reconstruction of professional identity, taking into account three educational stages, is a starting point on which to structure avariety of lines of research. In this research, and based on the approach taken, a clear reflective contribution is made on how to deal with PE in this COVID-19 situation. This may be of particular interest to teachers at each of the educational stages, enabling them to modify and transform their contexts.

\section{Is it the end of the physical education we all know?}

Regardless of the pedagogical models employed by the PE teacher and his or her approach to the subject, it has been framed in a curricular context with principles that have been unquestionable up to now: presence, contact between students, socialization... Until the arrival of the pandemic, it would have been unthinkable to be able to break some of these principles, since they support both the fundamental axis of the body's pedagogical treatment of the subject and the reflective approaches to health promotion (W iltshire, Lee\& Evans, 2017). It is necessary that the treatment of the body in PE is approached on the basis of student learning and participation. In this way, educational programmes must have a clear pedagogical orientation, using motor skills from a broad and transversal perspective. 0 nly in this 
way can the necessary inclusion within the subject be fostered, allowing students to gain meaningful learning experiences and thus improving their physical selfconcept (Hortigüela-Alcalá, Pérez-Pueyo \& Calderón, 2016). For this reason, it is essential that attention be paid to the pedagogical training that teachers must receive. On certain occasions, more hours of physical education are demanded solely and exclusively on the basis of obesity criteria, and this is something that does not benefit us as a subject (Pérez-Pueyo, Hortigüela Alcalá, Fernández-Fernández, Gutiérrez-García, \& Santos- Rodríguez, 2021). To this end, it is necessary to apply methodological and eval uative approaches in the subject that guarantee student involvement in the process, such asformative and shared assessment (BoresGarcía, Hortigüela-Alcalá, Hernando-Garijo \& González-Calvo, 2021) and the competency-based approach (Pérez-Pueyo, Vicente-Pedraz \& HortigüelaAlcalá, 2019).

This new situation strongly conditions the teaching staff, since practices that had been carried out normally in the classroom until now are now practically unfeasible. This generates a defenselessness among teachers that the political system and the educational administration must respond to in a decisive manner, something that does not al ways happen due to the control exercised over the autonomy of the educational community (Jessen \& DiMartino, 2020). In fact, in certain cases, highly mediatized and politicized protocols of action are established, which totally disfigure the essence of learning (G riggs \& Ward, 2012). This leads to an instability of the educational and curricular system that makes it necessary to reconfigure the aims of PE.

The maintenance of distance and the greater importance given by the educational administration to instrumental subjects such as language and mathematics have served to further intensify the discrimination to which PE has been subjected for decades (J ames, 2011), being politicized through the promotion of sport alone (Stirrup, 2020). This discredit, sometimes accompanied by a reduction in the time of the course, is highly counterproductive for the psycho-evolutionary development of the students, something that has repercussions on later adult life (Larouche, Laurencelle, Shephard \& Trudeau, 2015). Furthermore, it lacks any health logic in the face of COVID-19, as the subject can often be taught in open spaces, something that favours both social distancing and the functioning of the respiratory system. In view of these health terms, it is essential that this promotion from school is done under terms of equality and equal promotion, always giving priority to ethical and social values over purely competitive ones (Schenker, 2019). Faced with this new situation, which is not at all favourable for $\mathrm{PE}$, two fundamental questions arise: How can a qual ity PE with so many conditions and limitations be taught? Should the teaching community reflect on reconfiguring the aims of the subject? A third and perhaps more important question arises: are we facing a new starting point that offers opportunities to continue growing as a discipline?T hese deliberationsmust be approached from critical and highly reflective positions, since any change in this line must be based on strong pedagogical principles that meet three key objectives: a) maintaining rigor in the discipline; b) generating learning in the students; c) promoting socialization among students (Ciotto \& Gagnon, 2018). It is usually too common for PE to establish initiatives to change the course of the subject towards positions that are not contrasted and scientifically evidenced, which is clearly detrimental to the subject. Therefore, it is essential that PE teachers intentionally establish reflective processes in order to establish four key functions: a) making sense of unforeseen events, b) developing knowledge in action, c) making decisions on the ground and d) rebuilding teachers' belief systems (Jung, 2012). In fact, reviews conducted on reflective practice in PE (Standal $\&$ M oe, 2013) reflect the demand that teachers express for fostering communities of reflection among teachers.

Having addressed these aspects, it is necessary to contextual ise the situation of the pandemic in the Spanish context. It should be noted that in March 2019 the country was in a state of al arm, leading to a situation of confinement that lasted until J une. At the beginning of this confinement, there was a great deal of confusion among the teaching staff, since, from one day to the next; the subject was taught on-line, something that had never happened before in history. During these four months, with hardly any guidelines from the educational administration, the teachers adapted to the situation in the best possible way, recognizing serious problems in carrying out virtual teaching such as eval uation, the type of content to be taught and the maintenance of the weekly timetable (Baena-M orales, López-M orales \& GarcíaTaibo, 2020). Given thiscontext and chronological path, it is essential to analyze the perception that teachers have when teaching this new PE. This becomes much more relevant if we look at the different educational stages, which gives the subject a greater global nature and spectrum. For this reason, it is 
necessary to move from a questioned identity to a reconstruction of the professional identity, generating processes of teacher interrelation that favorsmotivation, authentic participation and responsibility (Clarke, 2009).

\section{Material and Methods}

\section{Participants}

Five university teachers (three women, two men), seven school teachers (four women, three men) and eight future teachers (four women, four men) participated. The university teachers (43.45 \pm 7.82 years) taught in the specialist PE program of two Spanish public universities. All of them had a PhD and more than seven years of experience in initial teacher training. All of them were full-time professors at the university, developing their professional career always at the same university. The school teachers ( $45.72 \pm 8.12$ years) taught in four schools in three different cities. Four in primary education and four in secondary education. They were all PE specialists, with more than 10 years of professional experience. Two of them were part of the management team of their schools, and all of them had worked in more than one school during their careers. The future teachers (21.45 \pm 1.54 years) were in their final year of their PE specialist undergraduate program at two Spanish public universities. All of them had already done their internships at the schools.

There was no connection between participants of the different educational stages, which prevented any bias and influence on their responses and the independent treatment of the results. All of them agreed to take part in the study on a voluntary basis, showing their willingness and active collaboration.

\section{Instruments}

Two different instruments were used to collect information. They were structured around the goal of the research project and the three categories in which the results are structured, thus obtaining greater linearity and consistency in the specificity of the data (Scott, 2004).

Reflectivejournals: Each participant teacher completed a reflective journal during his/ her the first two months of teaching of the 20-21 academic year. They wrote weekly to reflect how they conducted their classes in this new post-COVID-19 context. These journals have been found ideal for PE teachers to reflect on the pedagogical role that the body should play in their classes (González-Calvo, Varea \& M artínez-Álvarez, 2019).
They were semi-structured to allow each participant to reflect freely (Slotnick \& Janesick, 2011). The researcher team remained in contact with the participants via e-mail and W hatsapp to support and clarify. This is considered essential to guarantee that the information provided by the journal is consistent with the goals of the study (Smith \& Zajda, 2018). The journals lasted two months with the aim of seeing the initial impact of the change that the COVID19 course was teaching to PE teachers. The journal included three openended questions, closely related to the purposes of the research (table 1).

Table 1

Issues to reflect on in the participating teachers' reflective journals

1. What are the main elements that limit your teaching in Physical Education? (problems, limitations... )

2. What kind of changes have you made to adapt to this new context? (content, spaces, materials, interactions....)

3. Do you think that the school's aims and the teacher's role should change? Why? (objectives, pedagogy...)

Table 2

Basic script used for the discussion groups.

1- How did you feel when you taught PE in this new context?Was it as you expected?

2- Did it have anything to do with PE you knew?W hy?

3- Do you think this type of $P E$ involves the same type of learning?W hy?

4- Do you think that, as a teacher, you had to play a different role? What did you have to

change?

6 - How do you think PE teachers can best adapt to this context?

7 - Is there anything positive in all this?

Discussion groups: After two months of teaching, a discussion group was held with each class of participants independently. It was conducted on-line, via Microsoft Teams. It lasted 90 minutes and it was recorded for later analysis. The questions used to prompt responses were in line with the goals of the study and the categories of analysis (table 2). 0 ne member of the research team moderated the discussion trying to create a climate of participatory trust where each participant contributed when he/ she wanted. Each question was asked in order and the discussion did not move to the next one until all the participants had answered it (Del Rio-Roberts, 2011). This process allowed the researchers to collect information of each of the questions from all participants.

\section{Design and procedure}

Thestudy followed a qual itative, retrospective design of phenomenological nature, trying to understand an educational phenomena from the analysis of the participants' experiences and discourses (Mertens, 2005). The research was structured in four welldifferentiated phases:

Phase 1. Structuring thestudy and planning theintervention: The study arose from a deep reflection of the researchers on the need to assess how teachers faced PE teaching in the post-COVID 19 context. It seemed a great 
opportunity to analyse this «new reality» from the teachers' point of view. The usefulness and contribution of the research relied on the perceptions of teachers from different educational stages of how this context, never experienced before, affected their teaching. Participants were contacted to inform them about the research design and procedures.

Phase 2. Design and follow-up of the reflective journals: The research team selected the issues to reflect on in the journals and provided one copy to each participant. The procedure was fully explained to them, highlighting that they had to complete the journals weekly, during the first two months of teaching, in a totally open and reflexive way. In the case of the future teachers, their practice tutors were contacted to discuss the use of this diary as a reflective element, which they thought was a great idea. The researchers followed up the completion of the diaries, contacting the participants periodically to solve any doubts or misunderstandings.

Phase 3. Elaboration of the discussion groups: After the first two months of the 2020-21 school year, the three discussion groupsformed.T hey were conducted on-line, on different days, recording each session for later analysis. Participants were guaranteed that the data would be used exclusively for research purposes. Each one lasted approximately 90 minutes. The aim was to go deeper into the subject of the study to conduct a reflexive conversation in a relaxed atmosphere (Anyan, 2013).

Phase 4. Analysis of all the data: After data collection from each of the instruments used, all were transcribed and analysed with the help of the text analysis software WeftQ DA. The research team filtered any data that had nothing to do with the goals of the study.

To begin the project, permission was obtained from the main researcher's U niversity Ethics Committee. The participants were clearly informed about the purposes of the research. They were encouraged to answer as truthfully as possible, guaranteeing anonymity and confidentiality of their answers. They were and subsequently subject them to the techniques of triangulation, purification and saturation with the other data collection instruments (Tortorella, Viana \& Fettermann, 2015).

\section{Analysis used}

A qualitative approach has been used to find out in depth what the experiences of the teachers of the different stages are at the beginning of the school year in the situation of the COVID.19 The way in which they have adapted to this new era is analyzed, with emphasis on aspects related to the development of professional identity.To do so, it was essential to analyse the real contexts in which their daily practice takes pla ce, as well as their more personal and social dimension (Halquist \& M usanti, 2010). The main source of data is the assessments and experiences of those involved in the educational process (Commander $\&$ Ward, 2009). This allows for reflection on the study phenomenon and how the participants' reflections influence their own purposes of intervention, focusing mainly on interpretative models (Carrión-Martínez $\&$ De la Rosa, 2013). A triangulation is carried out between the information obtained from the data collection instruments, which is very positive as it allows for a multidimensional analysis of the research approach (Oliver-Hoyo \& Allen, 2006). Furthermore, there is a high cultural and social component around the same topic, the teaching of PE in the situation of COVID 19, which gives more identity and coherence to the qualitative educational approaches (Aydin \& Tonbuloglu, 2014). In order to guarantee the reliability, transferability and credibility of the results, a codification of the most significant text extracts was carried out in each of the instruments, using the cross matching patterns (Sal daña, 2009). All the information was articulated through the grouping in thematic axes in relation to the categories of the study, by means of a selective, open and axial codification.

\section{Generation of categories and their categorization}

Through the saturation of coinciding texts and ideas and the treatment of thematic axes, the information wasgrouped into the three initial categories of thestudy: a) reconfiguration of the aims of the subject; b) reconstruction of the professional identity; $c$ ) main limitations of the teaching and solutions found. From these categories the questions raised in the two data collection instruments derive, which has repercussions on the linearity of the structure of the research and the reliability of the results. These categories are related to the objective of study from the context studied, thus respecting the criteria of specificity and coherence that all qualitative research must have (Trainor $\&$ Graue, 2014).

- Reconfiguration of the aims of the subject: this deals with aspects related to the way in which teachers reflect on what the aims of the subject should beand the changes that are necessary in order to achieve them.

- Reconstruction of professional identity: This includes 
all the information regarding how this new situation in the teaching of PE has an impact on the way teachers teach and how they are restructured as physical educators.

- Main teaching constraints and solutions found: information obtained on all the problems encountered by teachers in this new COVID 19 situation is recorded as well as the strategies with which they deal with these constraints.

\section{Data coding}

Different acronyms are used to identify the text extracts with the data collection instrument from which they come. In relation to reflective journals, for univer sity teachers it is used (RUJ), for school teachers it is used (RTJ) and for future teachers it is used (RFJ). Regarding the discussion group, for university teachers it is used (UDG), for school teachers it is used (TDG) and for future teachers it is used (FDG).

\section{Results}

All the information extracted from the two data collection instruments is grouped into the three categories of the study. Through the analysis of crossed patterns, the number of resulting literal text extracts is presented, showing the most significant and coinciding ones (Saldaña, 2009). For a better understanding of the data, each of the categories is structured on the basis of the text extracts relating to each of the groups of participants, referencing the acronym of the instrument from which they come. In this way, each text excerpt presented is identified with the group of participants from which it originates.

\section{Reconfiguration of the purposes of the course: (314 text extracts).}

School teachers reflect how many pedagogical limitations are encountered by having to comply strictly with distancemeasures, individual use material and mask use, which makes them substantially modify their programming:

«It is impossible to think that physical education can be anything like what it used to be [...]». «Students have to keep their distance all the time, they are covered with their mask, what kind of socialization can we work on like this? ...] It is clear that we have to readjust the objectives of the subject. "Some contentsI have been able to change, others I have had to eliminate directly, so I assume I will teach lessy (RTJ).

"With this situation it is truly complex to maintain the essence of the teaching of the subject [... $]$.You spend more time checking that the rulesare being followed than you do teaching». «I honestly think that the learning isless, since you can't connect with the students as you used to». "It is very difficult to build trust in the group when your students are not allowed to touch their peers, «I know that you have to act and not complain, but the truth is that we cannot deny the reality» (TDG).

U niversity teachers argue that, in these times, it is essential to reconfigure the aims of the subject, as we cannot continue to teach the same thing or in the same way:

"COVID 19 has undermined the fundamental pedagogical aims of physical education, so we cannot think of teaching in thesameway [...]》. «Physical education isa fully social subject, and as such, it must connect with the situations in which society lives [...]. For this reason, it is essential that we, as a collective, agree on what the main lines of teaching of the subject should be, and, more importantly, how to do it» (RUJ).

"We cannot continue to teach in the same way in this situation. "If we are a conscientious and rigorous group, we will have to define the type of practices that pursue the corporal learning of the students beyond the classrooms [... ]. «lf we only use the subject as a tool for the prevention of sedentary life and obesity, we are condemned as a curricular subject» (UDG).

Future $P E$ teachers doubt that the training they have received at university will enable them to cope with this situation with any guarantees, something that makes them very uncertain about how to teach the subject:

"All the training we have received over the years has been about thephysical education we have known all our lives: contact, sharing material [...]. N ow, we have gone to the schools and we realize that this situation prevents everything we have learned from starting». "Adapting to a new situation when you have experience is easier than when you are new, that's why I find myself lost» (RFJ).

«In my first practiceat school I felt the typical initial nerves when faced with a new situation [...] but I knew what I had to do and how.» "You have the kids in front of you, separated, wearing their masks, you don't know if they are laughing or angry and you think, where do I start? «I suppose that in time we will adapt, but hopefully this situation will end as soon as possible» (FDG).

\section{Reconstruction of professional identity (309 text extracts)}

School teachers stress the need to restructure the concept of cooperation as opposed to the imposition of distance and individual ism. They stress the importance of working on emotions in the classroom and attending to the social and family contexts of the students: 
«With this situation, cooperation has been put on the back burner, and this issomething we must address [...]. Cooperation, even without contact, can and does happen, and it is very necessary in this very distressing social situation we are in. «Everyone talks about physical education now having to focus on the individual and the physical condition, but I think we have to go beyond that. "The fact that there is distance does not mean that we cannot work cooperatively» (RTJ).

«Subconsciously, a climate of mistrust, fear and insecurity towards others is being generated in society [...]. «M ore than ever, we have to attend to the emotions of the students, and physical education is ideal for this. «We must not forget that there are many families who are having a hard time in this situation, so we must be very tactful and propose activities that are fully inclusive and satisfactory». "The school must, more than ever, be a place of welcome» (TDG).

University teachers believe that in this situation it is essential to generate critical awareness in future PE teachers. They stress that the subject must be more transversal than ever, with the priority being to have a strong presence in the school:

«Initial teacher training is now a key issue [...]. It is a priority to encourage their critical reflection so that they can go beyond just teaching some content or others». "The policy and curriculum guidelines are related to eliminating the body of the school, and it is precisely now when it is most needed». «The body must not be worked on only in physical education, but must be addressed transversally in all subjects». «Wephysical educators have to make a strong reconstruction towards the transversality of the body» (RUJ).

"The importance of the teaching of physical education is not only about the content you teach students [...]. The key is what they can learn from it in their daily lives. "The transferability of learning in physical education is fundamental, bearing in mind the social, emotional, health and selfregulatory benefits of the subject [...] This is where we have to makea difference, by changing our teaching approach» (UDG).

PE future teachers believe that in this new and everchanging situation they have to train more than ever before to be able to adapt to any context in which they have to work. They emphasise the promotion of personal and social responsibility towards others that must be linked to the body:

«It is clear that methodology and evaluation are the fundamental axes of teaching [...] And this methodology in physical education must be based on fully educational and pedagogical aspects». «Today it is essential to master the social environment, dealing with families, understanding social realities [...]. «We do not know where we will have to work and under what conditions, so wehaveto beprepared for everything [... ] (RFJ).
"The more we are trained in these uncertain times, the better. «Physical education today has to be very much connected to social purposes. «We have to be aware of the need for students to be responsible with the use of their body and the way they interact with the environment. «The body, in all its dimension, has to go beyond the classroom and that is where I think we have to retrain ourselves》 (FDG).

\section{Main limitations of teaching and solutions found (321 text extracts)}

School teachers highlight as the main limiting factors the delimitation of the practice spaces, the respect towards the subject of their own classmates and the generation of trust among the students. The main solutions revolve around the delimitation of shared decisions with the students:

«Wehavealways had problemsdividing up the spaces between the teachers, especially when it was cold and one of them had to go to the street [... ]. But now it's practically impossible with the increasein distances, «It's painful to seehow your own classmates underestimate physical education, saying that we can use any place to do sport. "I have a hard time building up trust in the groups [...].You tell them to collaborate and do things together when they can't really touch or see each other's faces» (RTJ).

"At first I was afraid to think how the children would react to this situation which was so different for them [...] I was pleasantly surprised at how well they had adapted. «l think that it's us adults who often have to learn from the children and how to respect the rules. «It has been very useful for me to agree on things with them: contents, responsibilities, rules to follow [... ]» (TDG).

University teachers see the main limitations as not being able to develop experiences outside the classroom based on service learning and not being able to carry out practical interventionsin schools. The main solutions are argued in relation to the need to expose students to situations that are as real as possible to what they will encounter in the classroom:

"I have always tried to link my university classes with internships that connect directly to the school [...] This is impossiblein the current situation. «You know that it isnecessary for them to make as much contact as possible with what will be their professional reality, the children [...] N ow you can't do anything but teach in the university classrooms». «M ethodologies such as service learning are essential to connect the university with society, and now this is quite complicated to do» (RUJ).

"The best we can do is try to simulate practices that are as cl ose as possibleto what futureteachers will encounter tomor row. «Today more than ever they need to know how to apply content in different contexts, individualise learning and give rigour to 
the teaching of physical education in all the schools they work in» (UDG).

Future teachers highlight as main problems the implementation of groupingsin a pedagogical way, being able to individualise the material and control distance and hygiene measures. The main solution is to start the classes with the contents that are most motivating for the students:

«I know that I still have a lot to learn, but what I find most difficult is to control the groupings and to ensure that the safety distance is respected [...]. Children want to be with their friends and sometimes it is difficult to control this. «It is very difficult for me that the material is not shared [... so you can't practice any group sport?» «For example, with hand hygiene before and after, a lot of time is lost [...] Much of what I had planned to work on is impossible for me» (RFJ).

«I know that it may not bethe best thing to do, but as I have no experience, it has helped me in my first interventions that the students choose which games they want to play». "I think it is important to empathise with them, and they can be motivated by letting them decide a little [...] The key is to be able to combine this with maintaining respect for the teacher» (FDG).

\section{Discussion}

The aim of this study is, under the theory of teaching identity, to contrast how three groups of teachers from different educational stages teach PE with COVID 19, analysing the adaptations made in the classroom. The results obtained, grouped under the three categories of analysis, a) reconfiguration of the aims of the subject; b) reconstruction of the professional identity; c) main limitations of teaching and solutions found, reflect a reality of $P E$ that isfar removed from what it was before the pandemic, with different limitations being perceived by the teacher s of the different stages. This radical change has led to the need for teachers to reflect deeply on the idiosyncrasies of the subject and the aims that shape it. Thisconnects directly with the theory that has structured the present research on teacher identity and professional reconstruction (MacLure, 1993), since there is a need for PE teachers to discuss with themselves what their role and commitment to the profession should be. This means moving from a questioned identity to a reconstruction of professional identity (Clarke, 2009), encouraging self-reflection that goes beyond the most repressive cultural and social discourses of power (Foucault, 1997). In thisregard, it isessential to highlight the radical change that has taken place in the teaching of PE in the COVID-19 situation. There are many fears and insecurities among teachers, as the subject has lost substantial elements of its idiosyncrasy. However, it is essential to reconfigure negative thoughts into concrete actions that will help us to continue to grow as a group, seeking alternatives that promote the rigour of the subject. We must be aware that this is a temporary situation that will sooner or later return to normal.

In relation to the first category, concerning the reconfiguration of the aims of the subject, the teachers in the schools have reflected that it is impossible for them to achieve the objectives they had set, since aspects such as social distance, the use of the mask or the use of the material individually, prevent them from following their programming normally. In this sense, university teachers reaffirm the need to reconfigure the aims of the course, stressing the impossibility of continuing to teach PE in the same way. This reflectsthe need to rethink teaching as the main tool for educational advancement (Wyant \& Baek, 2019). As indicated by Backman and Barker (2020), the use of the body in the area of higher education must be integrated into reflective thinking and with a tendency to adapt to and question the prevailing social and cultural realities. On the other hand, the future teachers in this study doubt whether the training they have received over the years at university really enables them to adapt to this new way of teaching the subject. In some countries, PE still takes place online, which teachers say is inappropriate and not very pedagogical (Kirbas, 2020). O ne of the most dangerous aspects of this pandemic situation is that the initial training of PE teachers is clearly limited, and we are faced with a new paradigm in which the body does not enjoy as much presentiality as it should (Lu, Barrett $\&$ Lu, 2020). In this sense, Shiver, Richards, Andrew and Hemphil (2020) stress that initial teacher training must be structured under solid principles of adaptability to the real professional contexts in which practice can take place, combining this with methodological resources for action based on culture and social justice.

$W$ ith regard to the second category of analysis of results, concerning the reconstruction of professional identity, the results of the research have shown how school teachersstress the need to restructure the current conception of cooperation in the face of compulsory distance. They stress the importance that must be given, more than ever, to the work of emotions and the link with families. In this sense, Walker and Johnson (2018) indicate that cooperation in PE must go far beyond physical contact and emotional control, and that it is an ideal teaching model for the acquisition of cognitive 
aspects and the promotion of reflection. Along these lines, studies such as that by Tiberi, Flores and Laughlin (2020) show how the creation of social links between students through cooperative learning in Secondary Education made it possible to increase reading comprehension scores. Physical experiences are a clear trigger for students' state of mind, which must be addressed by teachers to try to connect with them and understand their reality (Papageorgaki, 2018). For their part, the university teachers in this study have stressed that in this pandemic situation it is essential to promote critical awareness among future teachers in PE, seeking to address the transversality of the body in the school. This connects with the statements made by future teachers, as they highlight the need for training in a multidisciplinary manner towards the responsibility of educating about the body. In this sense, González-Calvo, Hortigüela-Alcalá and Fernández-Bal boa (2019), analyse the factors that influence the corporal subjectivities of PE teachers, showing how the conception of their own body revolves fundamentally around physical appearance and ability, influencing three levels: a) personal; b) intrapersonal; c) socio-cultural. This leads to profound reflections by PE teachers, establishing the component of critical action as a means of acting on the dominant body discourses established at a political and social level (Beltrán-Carrillo, Devís-Devís \& Peiró-Velert, 2018).

W ith regard to the third category of analysis of results, relating to the main limitations of teaching and solutions found, teachers in the schools perceive as the main limitations the delimitation of practice spaces, respect for the subject of their own classmates and the generation of trust among students. This vision is shared by future teachers, who also add the limitations of carrying out groupings and being able to control distance and hygiene measures. In both cases, they recognise that the content that generates the most motivation and interest is agreed with the students. In view of this, Ferkel, Razon, Judge and True (2017) establish the importance of establishing a balance between the priorities of the students and the contents of the work in the classroom, not confusing mere fun with real motivation to practice physical activity. In order for this motivation to be related to the specific contexts of PE practice, it is essential that teachers reflect on the influence of the practice spaces within the classroom (González-Calvo, HortigüelaAlcalá\& Martínez, 2018). For their part, the university teachers in this study perceive the main current limitation as not being able to carry out practical interventions in schools. This clearly limits the application of certain pedagogical models such as Service Learning, which, when applied in the initial training of PE teachers, has shown positive effects on their motivation and academic performance (Gil-Gómez, Chiva-Bartoll and Martí-Puig (2015).

\section{Conclusions}

The article has reflected the first experiences of physical education teachers, from different educational stages (including future teachers), in the situation of COVID 19. It has been verified how they present a diversity of fears, insecurities and problems that they try to solve in the best possible way according to their possibilities. In this situation of uncertainty and helplessness, they recognise that PE loses its pedagogical sense when such important restrictions are imposed as distance, not being able to share material and the use of the mask, among others. This leads to the need for a strong reflection as a collective on the reconfiguration of the aims of the subject and the reconstruction of the professional identity of teachers, using this situation of pandemic as a possibility of reconversion and growth as a discipline. This manuscript represents a substantial contribution to the existing literature on the subject, as, to date, no research has been published that compa res the perceptions of PE teachers from different educational stages on how to teach the subject with the pandemic. These perceptions have been framed in the theory of teaching identity and professional reconstruction, trying to generate a profound reflection among teachers in the school in order to: a) give rigour and coherence to the subject; b) rethink pedagogical practice to verify the learning that emanates from the school; c) demand what their place should be in the school as a discipline.

The manuscript may be of real interest to all teachers in the school, as it will allow them to analyse, from an intraper sonal perspective, the role that they should play as teaching professionals in this pandemic situation. It will also be of interest to all legislators and those responsible for drawing up educational curricula, as it will demonstrate the need for the body to be addressed pedagogically and transver sally in the school. As a future line of research, and taking into account the limitations of the research, it would be interesting to carry out more longitudinal research to check the adaptations made and the evolution of the teaching staff throughout the academic year. In addition, interventions could be 
carried out with a larger number of participants and different groupings of teachers could be established according to the context in which they teach. It is essential to continue researching the professional performance of the school at this stage of such radical change, as it is a crucial moment to reflect on and demonstrate the full potential of the subject.

\section{References}

Anyan, F. (2013). The Influence of Power Shiftsin D daCollection andAnalysisStages:A Focuson Q ualitaive Research Interview. Qualitative Report, 18(1), 45-63. 2013.

Aydin, H., \&Tonbuloglu, B. (2014). GraduateStudentsPerceptions' on Multicultural Education: A Q ualitativeC aseStudy. Eurasian Journal of Educational Research, 57(1), 29-50. doi: https:/ / doi.org/ 10.14689/ ejer.2014.57.3.

Backman, E., \& Barker, D.M. (2020). ReThinking Pedagogical Content Knowledge for Physical Education Teachers Implicationsfor Physical EducationTeacher Education. Physical Education and Sport Pedagogy, 25(5), 451-463. doi: http:/ / dx.doi.org/ 10.1080/ 17408989.2020.1734554.

Bæna-M orales, S., López-Morales, J., \& GarcíaTaibo, 0. (2020). Teaching intervention in physical education during quarantine for COVID-19. Retos, 39, 388-395.

Beltrán-Carrillo, V.J., Devís-D evís, J., \& Peiró-Velert, C. (2018). The Influence of Body Discourses on Adolescents' (Non)Participation in Physical Activity. Sport, Education and Society, 23(3), 257-269. doi: http:/ / dx.doi.org/ 10.1080/ 13573322.2016.1178109.

Bores-García, D., HortigüelaAlcalá, D., Hernando-Garijo,A., \& González-Calvo, G. (2021). Analysis of student motivation towards body expression through the use of formative and share assessment. Retos, 1(40), 198-208. https:/ / doi.org/ 10.47197/ retos. v1i40.83025

Carrión-Matínez,J.J., \& LuqueDelaRosa,A. (2013). Methodology and Resources of the Itinerant Speech and Hearing Teacher. Electronic Journal of Research in Educational Psychology, 11(2) 501-526.

Ciotto, C.M., \& Gagnon, A.G. (2018). Promoting Social and Emotional Learning in Physical Education. Journal of Physical Education, Recreation \& Dance, 89(4), 27-33. doi: http:// dx. doi.org/ 10.1080/ 07303084.2018.1430625.

Clarke, M. (2009). The Ethico-politics of Teacher Identity. Educational Philosophy andTheory. Philosophy ofteading, 41(2), 185-200.

Commander, N.E., \&Ward, T. (2009). Assessment matters:The strength of mixed research methods for the assessment of learning communities. About Campus, 14(3) 25-28. doi: $10.1002 /$ abc. 292.

Del Rio-Roberts, M. (2011). How I Learned to Conduct Focus Groups. Qualitative Report, 16(1), 312-315.

Ferkel, R.C., Razon, S., Judge, L.W., \&True, L. (2017). Beyond
«Fun»:The Real Need in Physical Eduction. Physical Educator, 74(2), 255-268. doi: https:/ / doi.org/ 10.18666/ TPE-2017V74-12-7426.

Foucault, M. (1997). The Ethics of the Concern of the Seff, Ethics, Subjectivity and Truth:The essential works of Foucault 1954- 1984. NewYork: The New Press

Gil-Gómez, J., Chiva-Bartoll, 0., \& M artí-Puig, M. (2015).The Impact of Service Learning on the Training of PreService Teachers:A nalysisfrom aPhysical Education Subject. European Physical Education Review,21(4), 467-484. http:/ / dx. doi.org/ $10.1177 / 1356336 \times 15582358$.

González-Calvo, G., HortigüelaAlcalá, D., \& Martínez, L. (2018). Lainfluencia de los espacios parael desarrollo del proceso de enseñanzal aprendizaje en educación física: una perspectiva autoetnográfica. Retos, 34, 317-322.

González-Calvo, G., HortigüelaAlcalá, D. \& \& Fernández-Balboa, J. M. (2019). Foci and factors that contribute to physical educators' construction of their professional body subjectivities: aqualitative study. Sport, Education and Society, 25(3), 292-304. doi:10.1080/ 13573322.2019.1578206.

González-Calvo, G.,Varea,V., \& M artínez-Álvarez, L. (2019). Health and BodyTensions and Expectations for Pre-Service Physical EducationTeachersin Spain. Sport, Education and Society, 24(2), 158-167. http:/ / dx. doi. org/ 10.1080/ 13573322.2017.1331426.

Griggs, G., \&Ward, G. (2012). Physical Education in the UK: Disconnectionsand Reconnections. Curriculum Journal, 23(2), 207-229. doi: http:// dx. doi.org/ 10.1080/ 09585176.2012 .678500$.

Håkansson, M., Kronlid, D. O., \& Östman, L. (2019). Searching for the Political Dimension in Education for Sustainable Development: Socially Critical, Social Learning and Radical Democratic Approaches. Environmental Education Research, 25(1), 6-32. doi: http:// dx. doi.org/ 10.1080/ 13504622.2017.1408056.

Halquist, D., \& Musanti, S.I. (2010). Critical incidentsand reflection: Turning points that challenge the researcher and create opportunities for knowing International Journal of Qualitative Studies in Education, 23(4), 449-461. doi: https: / / doi.org/ 10.1080/09518398.2010.492811.

Herold, F., \& Waring, M. (2017). Is Practical Subject Matter Knowledge Still Important? Examining the Siedentopian Perspective on the Role of Content Knowledge in Physical Education Teacher Education. Physical Education and Sport Pedagogy, 22(3), 231-245. doi: http:/ / dx. doi. org/ 10.1080/ 17408989.2016.1192592.

H ortigüelaAlcalá, D., Pérez-Pueyo, A., \& Calderón, A. (2016). Efecto del modelo de enseñanza sobre el autoconcepto físico del alumnado en educación física. Retos. Nuevas tendencias en Educación Física, Deportey Recreación, 30,76-81.

James, A.R. (2011). The Marginalization of Physical Education: Problemsand Solutions. Journal of Physical Education, Recreation $\&$ Dance, 82(6), 15-16.

Jessen, S.B., \& DiMartino, C. (2020). Rearranging the Chairs on 
the Deck orTrue Reform? PrivateSector Bureaucraciesin the Age of Choice- An Analysis of Autonomy and Control. Educational Policy, 34(1), 239-260. doi: http:// dx.doi.org/ $10.1177 / 0895904819881782$.

Jung, J. (2012). The Focus, Role, and Meaning of Experienced Teachers' Reflection in Physical Education. Physical Education and Sport Pedagogy, 17(2), 157-175. doi: http:/ / dx. doi.org/ 10.1080/ 17408989.2011.565471.

Kirbas, S. (2020). The Views of Physical Education and Sports Teaching Instructors on Education in the COVID-19 Period. Journal of Education and Learning, 9(6), 196-205.

Landi, D., Fitzpatrick, K. \& M cGlashan, H. (2016). M odelsBased Practices in Physical Education: A Sociocritical Reflection. Journal of Teaching in Physical Education, 35(4), 400-411. doi: http:/ / dx. doi.org/ 10.1123/ jtpe.2016-0117.

Larouche, R., Laurencelle, L., Shephard, R.J., \&Trudeau, F. (2015). Should the Curricular Time Allocated to School Physical Education Be Increased? Insightsfrom ParticipantsinaFollowup of theTrois-Rivières Study. Physical Educator, 72(4), 701720. doi: http:/ / dx.doi.org/ 10.18666/ TPE-2015-V72-146276.

Lu, C., Barrett, J., \& Lu, 0. (2020). Teaching Physical Education Teacher Education (PETE) O nline: Challenges and Solutions. Brodk Education: A Journal of Educational Research and Practice, 29(2), 13-17.

MacLure, M. (1993)Arguing forYour Self: Identity asan organising principlein teachers' jobs and lives. British Educational Research Journal, 19(4), 311-322.

Mertens, D. (2005). Research and evaluation in Education and Psychology: integrating diversity with quantitative, qualitative, and mixed methods. Thousand 0 aks: Sage.

Oliver-Hoyo, M., \& Allen, D. (2006). The use of triangulation methods in qualitative educational research. Journal of College Science Teaching, 35(4), 42-47.

Papageorgaki, Z.K. (2018). Researching the Lived Experience of Physical Education: SomePedagogical Insights. Sport, Education and Society, 23 (9), 916-927. doi: http:/ / dx.doi. org/ 10.1080/ 13573322.2017.1278586.

Pérez-Pueyo,A., Hortigüela-Alcalá, D., Fernández-Fernández, J., Gutiérrez-García, C., \& Santos-Rodríguez, L. (2021). Más horassí, pero ¿cómo implantarlassin perder el enfoquepeda gógico de la Educación Física? Retos, 39, 345-353.

Pérez-Pueyo, A., Vicente-Pedraz, M., \& Hortigüela-Alcalá, D. (2019). ¿Por qué y para qué de las competencias clave en educación física? A nálisis de dos posturas contrapuestas. Retos, 35, 7-12.

Saldaña, J. (2012). The coding manual for qualitative researchers. Thousand 0 aks: Sage.

Schenker, K. (2019). Teaching Physical Activity- A M atter of Health and Equality?Scandinavian J ournal of Educational Reesarch, 63(1), 53-68. doi: http:// dx.doi.org/ 10.1080/ 00313831.2017 .1324903$.

Scott, K.W. (2004). Relating Categories in Grounded Theory Analysis: Using a Conditional Relationship Guide and
Reflective Coding Matrix. Qualitative Report, 9(1), 113-126.

Shiver,V.N., Richards, K., Andrew, R., \& Hemphil, M.A. (2020). Preservice Teachers' Learning to Implement Culturally Relevant Physical Education with theTeaching Personal and Social Responsibility Model. Physical Education and Sport Pedagogy, 25(3), 303-315. d oi: http:/ / dx. doi.org/ 10.1080/ 17408989.2020.1741537.

Slotnick, R.C., \& Janesick,V.J. (2011). Conversationson M ethod: Deconstructing Policy through the Researcher Reflective Journal. Qualitative Report, 16(5), 1352-1360.

Smith, K., \& Zajda, J. (2018). Q ualitative and Quantitative Methodologies:A M inimalistView. Education and Society, 36(1), 73-83.

Standal, O.F., \& Moe, V.F. (2013). Reflective Practice in Physical Education and Physical EducationTeacher Eduction:A Review of the Literaturesince 1995. Quest, 65 (2), 220-240. doi: http:/ / dx. doi.org/ 10.1080/ 00336297.2013.773530.

Stirrup, J. (2020). Performance Pedagogy at Play: Pupils Perspectives on Primary PE. Sport, Education and Society, 25(1), 14-26. doi: http:// dx.doi.org/ 10.1080/ 13573322.2018.1554562.

Tiberi, S., Flores, I., \& Laughlin, M. K. (2020). Cooperative Learning in Physical Education and Its Effects on Student Reading Comprehension Scores. Physical Educator, 77 (2), 294-312. doi: https: / / doi.org/ 10.18666/ TPE-2020-V77-I2-9200.

Tortorella, G. ,Viana, S. \& \& Fettermann, D. (2015). Learning cycles and focus groups: A complementary approach to the A3 thinking methodology. The Learning Organization, 22(4), 229240.

Trainor, A., \& Graue, E. (2014). Evaluating rigor in qualitaive methodology and research dissemination. Remedial and Special Education, 35(5), 267-274. doi: https:/ / doi.org/ 10.1177/ 0741932514528100.

Varea,V., \& González-Calvo, G. (2020). Touchlessclassesand absent bodies: teaching physical education intimes of Covid-19. Sport, Education and Society (online).

Walker, E., \& Johnson, I.L. (2018). Using Best PracticesW hen Implementing the Cooperative-LearningT heory in Secondary Physical Education Programs. Strategies: A Journal for Physical and Sport Educators, 31(4), 5-11. doi: http:/ / dx. doi.org/ 10.1080/ 08924562.2018.1465870.

Wiltshire, G., Lee, J. , \& Evans, J. (2017). «You Don'tWantto Stand out asthe Bigger O ne»: Exploring How PE and School Sport Participation Is Influenced by Pupils andTheir Peers Physical Education and Sport Pedagogy, 22(5), 548-561. doi: http:// dx. doi.org/ 10.1080/ 17408989.2017.1294673.

Woodrow, K., \& Caruana, V. (2017). Preservice Teachers' PerspectiveTransformations as Social ChangeAgents. Journal of Transformative Education, 15(1), 37-58. doi: http:// dx.doi.org/ 10.1177/ 1541344616655887.

Wyant, J., \& Baek, J.H. (2019). ReThinkingTechnologyAdoption in Physical Education. Curriculum Studies in H ealth and Physical Education, 10(1), 3-17. doi: http:/ / dx. doi.org/ 10.1080/ 25742981.2018.1514983. 